\title{
Monastycyzm w świecie duchowości ponowoczesnej. Organizacja Morska zakonem religijnym Kościoła scjentologicznego
}

\begin{abstract}
Article synthetically describes the history, assumptions and a short description of the Religious Order of the Scientology - Sea Organisation, which was founded in 1967, thirteen years after when in Los Angeles was registered the first institution of the Church of Scientology. The text of the article is based on three basic types of sources: literature, memoirs of former members of the order and the relationship of current active monks, the information from whom was received at query time research at the Ideal Orgs (headquarters) of the Church in Spain and Hungary in 2016. Apart from presenting the image of contemporary monasticism in terms of the Scientology also is explained the basic religious concepts, that relevant for this Ron Hubbard's cult. The last part of the article is devoted to the symbolism of the Sea Org, which is really a reflection of the ideological assumptions that entity.
\end{abstract}

Keywords: auditor, D. Miscavige, the Church of Scientology, L. Ron Hubbard, new religious movements, Operating Thetan, Sea Org

\section{Zagadnienia wprowadzające: monastycyzm a religia}

W iększość tradycji religijnych w celu umożliwienia swoim najbardziej oddanym adeptom większego angażowania się na rzecz wspólnoty zbudowały przestrzeń dla stowarzyszeń, w których członkowie mogą poświęcić cały swój wy- 
siłek egzystencjalny służbie religijnej. Częstokroć owe wspólnoty mają konkretne określone cele i działają w ramach zorganizowanej społeczności, istotnie różniących się tak formą organizacji, jak również porządkiem działania. Na przykład, w tradycji chrześcijaństwa wschodniego trudno doszukiwać się poszczególnych zakonów mniszych, jak to tradycyjnie się przyjęło na Zachodzie, gdyż każdy mnich lub mniszka należą tam do jednej rodziny duchowej ${ }^{1}$. Niektórzy z członków tych grup mieszkają w ściśle zorganizowanych ośrodkach i podporządkowują się regułom o zaostrzonym rygorze, drudzy zaś mogą przypominać luźno rozproszone jednostki.

Członkowie tychże struktur są znani z praktyk, które, owszem, mieszczą się w granicach ich systemu wyznaniowego, ale stanowią one differentia specifica wybranej, czasem nielicznej, grupy osób, bowiem specjalne zadania i dyscyplina nie są wymogiem dla pozostałych przedstawicieli tejże religii. Nieraz te osoby wyróżniają się nie tylko swoim powołaniem lub praktykami, lecz także w sposób zdecydowanie inny przebiega ich ziemskie życie: specyficzny ubiór, dieta, asceza i wstrzemięźliwość seksualna². To wszystko powoduje, że w ramach rzeszy wiernych wyodrębniamy oddzielną społeczność, nazywaną wspólnotą mniszą.

Monastycyzm (z greckiego $\mu$ ovoxós - samotny) jest rodzajem praktyki religijnej, polegającej na zrzeczeniu się życia doczesnego na ziemi w celu poświęcenia się pracy duchowej na rzecz wyznawanej religii, całkowite oddanie priorytetom duchowym. Monastycyzm jest praktyką znaną nie tylko w tradycji chrześcijańskiej, lecz również w judaizmie, hinduizmie, buddyzmie, islamie. Rozwój religijności oraz powstawanie nowych ruchów religijnych od drugiej połowy XIX wieku powoduje także rozwój nowego monastycyzmu, nie zawsze zresztą związanego z konkretną tradycją religijną. W swoich manifestach tzw. nowi mnisi twierdzą, że są powołani do tworzenia „małych wspólnot przyjaciół, odkrywania unikalnego powołania każdej osoby i każdej wspólnoty”3. Podobnego rodzaju struktury trzymają się z dala od dogmatów znanych religii, chcą raczej odkryć świat na nowo, akceptując każdego człowieka

W obrębie nowych i alternatywnych ruchów religijnych rozwinęły się wariacje na temat życia monastycznego. Wśród ciekawszych z nich można wymienić Organizację Morską Kościoła scjentologicznego, która zostanie tu omówiona.

W połowie XX wieku na terenie USA Lafayette Ronald Hubbard (1911-1986) założył organizację, która szybko się rozwijając, miała wkrótce swoje przedstawi-

${ }^{1}$ Zob. J. Séguy, A Sociology of Imagined Societes: Monasticism and Utopia, w: Annual Review of the Sociology of Religion: Volume 5: Sociology and Monasticism. Between Innovation and Tradition, red. I. Jonveaux, E. Pace, S. Palmisano, Leiden-Boston 2014, s. 292.

${ }^{2}$ Chociaż tu też mogą być wyjątki. Na przykład w wywodzącej się z hippisowskiego ruchu Jezusa (ang. the Jesus Movement) grupie Dzieci Boga nie było nie tylko wstrzemięźliwości, lecz wręcz seks stał narzędziem krzewienia swoich poglądów. Na ten temat zob. W.S. Bainbridge, The Endtime Family: Children of God, New York 2002, s. 6.

${ }^{3}$ R. McEntee, A. Bucko, New Monasticism: An Interspiritual Manifesto for Contemplative Life in the 21st Century, New York 2015, s. 1.

${ }^{4}$ R. McEntee, A. Bucko, New Monasticism: An Interspiritual Manifesto for Contemplative Life in the 21st Century, „Kosmos” Spring | Summer 2013, s. 67. 
cielstwa i placówki misyjne niemal na każdym kontynencie. Kościół scjentologiczny (KS) - taką nazwę obrał sobie nowy ruch religijny (NRR) - oprócz propozycji praktyk i ćwiczeń o charakterze duchowym zaproponował swoim wiernym także możliwość uczestniczenia wraz z głębokim poświęceniem na rzecz rozpowszechniania nauk Mistrza ${ }^{5} \mathrm{w}$ nieco inny sposób - powstała organizacja przypominająca zakon religijny, a obowiązki i reguły, którym podporządkowują się adepci, stały niemalże nową formą życia monastycznego ${ }^{6}$.

Każde studium Kościoła scjentologicznego nierzadko napotyka szereg problemów natury metodologicznej, bowiem istnieje ogrom literatury (w tym również firmowanej logo samego Kościoła Hubbarda), gdzie jest zawarty opis praktyk, rytuałów i nauk L. Rona, a ponadto wielce złożona i rozbudowana eklezjalna struktura omawianego NRR może być przyczyną dodatkowych trudności w sięgnięciu do ważnej, a zarazem istotnej informacji, o czym chociażby wspomina prof. John Gordon Melton (ur. 1942), dyrektor-założyciel Amerykańskiego Instytutu Badań nad Religią, a jednocześnie autor jednego z największych zbiorów materiałów na temat Kościoła scjentologicznego, zdepanowanego w ramach American Religion Collection Biblioteki Davidsona przy Uniwersytecie Kalifornijskim w Santa Barbara ${ }^{7}$.

W przeciwieństwie do wielu innych młodych i alternatywnych religii, na temat scjentologii powstało mnóstwo publikacji, w tym dosyć krytycznych. Literatury na temat zakonu scjentologicznego nie jest jednak dużo - pierwsza uwaga odnośnie do Organizacji Morskiej w literaturze scjentologicznej pojawiła się dopiero w obszernym dziele What is Scientology? z końca lat 90 . minionego stulecia ${ }^{8}$. Należy jednak wspomnieć również o serii historii dotyczących Organizacji Morskiej w cyklu wykładów L. Rona Hubbarda dla członków Kościoła z lat 60 . XX wieku9 .

W tym artykule nie jest podejmowana próba zajęcia stanowiska w sprawie prawdziwości lub fałszywości religii scjentologicznej. Ten zakres opinii - popierających lub przeciwnych wierzeniom i praktykom Kościoła Hubbarda - stanowi ocenę teologiczną i zasługuję na oddzielne omówienie. Aczkolwiek, podobnie jak w przypadku wielu innych religii, w tym także tradycyjnych, istnieje wiele osób, które przystąpiły do organizacji, uczestniczyły w jej praktykach, lecz później odeszły z ruchu, tracąc wiarę w duchowy komponent koncepcji scjentologicznej bądź nawet kwestionując religijny status scjentologii jako takiej.

${ }^{5}$ Mistrz, Założyciel, Komodor, Ron, Źródło, LRH, Ojciec - są to zamienniki imienia L. Rona Hubbarda, twórcy scjentologii, częstokroć używane w metajęzyku wyznawców tej doktryny - Aut.

${ }^{6}$ K. Pouw, Church of Scientology International and Religious Technology Center Win in Court Against Former Member, Release of the Church of Scientology International, 2.04.2010, s. 2.

7 J. Gordon Melton, A Contemporary Ordered Religious Community: The Sea Organisation, „The Journal of CESNUR” 2018, vol. 2, nr 2, s. 22.

${ }^{8}$ Church of Scientology International, What is Scientology? The Comprehensive Reference on the World's Fastest Growing Religion, Los Angeles 1998, s. 654.

${ }^{9}$ Zob. L. Ron Hubbard, 2 D. Effective, „Flag Order” 13 January 1969, nr 1729. 


\section{Erygowanie i początkowy okres istnienia Organizacji Morskiej}

Rozpatrując scjentologię jako całościowy system religijny, nie można pominąć najstarszej formacji ${ }^{10}$, która, mimo że nie jest oficjalnie włączona w piramidę eklezjalną kierownictwa kościelnego oraz nie jest komórką zrzeszoną, tym niemniej zapewnia personel prawie wszystkim kondygnacjom w Kościele ${ }^{11}$, poczynając od trzeciego szczebla w hierarchii, czasem nadzorując też pracę misji ${ }^{12}$. We wrześniu 1967 r. została powołana do życia Organizacja Morska (ang. Sea Organisation; w skrócie: Sea Org), rodzaj elitarnego zakonu religijnego, zrzeszającego najbardziej oddanych członków Kościoła ${ }^{13}$. Był to nowy etap w biografii Założyciela, kiedy, rezygnując z dotychczasowego stanowiska Dyrektora wykonawczego i przekazując stery rządów Kościołem zaufanym współpracownikom ${ }^{14}$, L. Ron przenosi się na pokład statku w celu dogłębnej analizy i kwerendy śladów byłych ziemskich cywilizacji; zakon natomiast miał wspierać swego guru w tych poczynaniach ${ }^{15}$.

Mimo że de iure Sea Org nie jest częścią organizacji, to wszystkie przynależące do niej osoby stanowią kadrę scjentologii wraz z innymi duchownymi, funkcjonariuszami i administracją; jest to prawdziwa elita scjentologii, crème de la crème $e^{16}$, scjentologiczna arystokracja ${ }^{17}$. Personel korpusu Sea Org zajmuje wysokie stanowiska urzędnicze, są odpowiedzialni za pracę z mediami, oficjelami z kręgów politycznych ${ }^{18}$. Zakon ten często budzi duże kontrowersje, a przez to zainteresowanie ze strony badaczy fenomenu religii $\mathrm{LRH}^{19}$.

Historia Sea Org rozpoczęła się na pokładzie trzech statków: Diana, Atena i Apollo (pierwotne nazwy Avon River, Enchanter oraz Royal Scotsmann) ${ }^{20}$, i to właśnie dlatego przez niektórych autorów, którzy poświęcili swoje prace temu

${ }^{10}$ C. Vosper, The Mind Benders. Scientology [PDF], London 1971, s. 107.

${ }^{11}$ F.K. Flinn, Scientology: The Marks of Religion, w: Scientology: Theology and Practice of a Contemporary Religion, red. Church of Scientology International, Los Angeles 1999, s. 156.

12 E. Townsend, The Sad Tale of Scientology: A short history 1950-1985, Stockport 1985, s. 54.

${ }^{13}$ H.B. Urban, The Church of Scientology: A History of a New Religion, Princeton 2011, ss. $122-123$.

14 J.R. Lewis, Introduction, w: Scientology, red. J.R. Lewis, Oxford 2009, s. 5.

${ }^{15}$ М.И. Одинцов, Лафайет Рональд Хаббард: биография человека, w: Свобода совести в России: исторический и современный аспекты. Выпуск 7. Сборник статей, red. М.И. Одинцов, Н.И. Щемелёва, Л.А. Ли, Санкт-Петербург 2009, s. 29.

${ }_{16}$ M. Wakefield, Understanding Scientology: The Demon Cult, Raleigh 2010, s. 209.

${ }^{17}$ R. Wallis, The Road to Total Freedom: A Sociological Analysis of Scientology, New York 1977, s. 140.

${ }^{18}$ Г.А. Кукушкина, Церковь Саентологии: основы вероучения, культовая и внекультовая практика (социально-философский анализ), Москва 2003, ss. 63-64.

19 J. Gordon Melton, Birth of a Religion, w: Scientology, red. J.R. Lewis, ss. 26-27.

${ }^{20}$ L. Ron Hubbard Library, The L. Ron Hubbard Series - Master Mariner: At the Helm across Seven Seas, Glostrup 2012, ss. 117-123. 
tematowi, ta niewielka flota była typologizowana jako prywatne siły morskie Założyciela ${ }^{21}$. Na pokładzie statku flagowego Apollo skoncentrowała się bardziej doświadczona grupa scjentologów, aczkolwiek większość z nich nie miała żadnego doświadczenia w nawigacji i wszystkiego musiała się uczyć od podstaw. W celu szkolenia zawodowego załogi zostały powołane dwie struktury - Pursers Project Force i Stewards Project Force. Idea szkoleń w miejscu pracy okazała się integralną częścią ewolucji Organizacji Morskiej, a pokłady statków stały się miejscem testowania niewielkiej liczby wybranych osób.

Na statkach powstało swoiste laboratorium do eksperymentów i namysłu nad tym wszystkim, o czym Komodor pisał w swoich licznych pracach. Celem, do jakiego została powołana owa formacja, było wspieranie L. Rona w jego zaawansowanych badaniach nad metodami scjentologii (zwłaszcza w doświadczeniach eksterioryzacji, częściej określanej jako out-of-body experience) oraz w nadzorowaniu całej sieci placówek kościelnych, pajęczyna których wówczas okalała planetę $^{22}$. Swoim istnieniem zakon nawiązuje do jednego z sekretnych mitów założycielskich ${ }^{23}$ - Organizacja Morska jest podobna do grupy Lojalnych Oficerów, którzy obalili międzygalaktycznego tyrana, władcę o imieniu Xenu²4.

Wszyscy powołani kandydaci byli wcześniej uznani za osoby, które osiągnęły tzw. status Clear ${ }^{25}$, a niektórzy z nich nawet OT (ang. Operating Thetan) ${ }^{26}$. Zanim kandydaci zostaną dopuszczeni do szeregów Sea Org, są zobowiązani do odbycia nowicjatu o nazwie Estates Projecte Force (EPF). Przed rozpoczeciem procesu wchodzenia do struktury SO, rekruci muszą zamknąć bieżące sprawy, gdyż wielu z nich bywa aktywnymi członkami Kościoła i pełni przeróżne funkcje na poziomie

${ }^{21}$ D. de Chant, D.L. Jorgensen, The Church of Scientology: A Very New American Religion, w: World religions in America: an introduction, red. J. Neusner, Louisville 2003, s. 225.

${ }^{22}$ Stephen A. Kent, profesor na Wydziale Socjologii na Uniwersytecie Alberta w kanadyjskim Edmonton, uważa, że przynajmniej jednym z powodów ustanowienia Sea Org był napotkany przez Kościół opór ze strony różnych urzędów w USA, UK, Australii i Rodezji. Żeglarstwo więc na otwartym morzu pozwalało uciec ich uwadze. Zob. J. Atack, A Piece of Blue Sky: Scientology, Dianetics and L. Ron Hubbard Exposed, New York 1990, s. 120; L. Wright, Droga do wyzwolenia. Scjentologia, Hollywood i pułapki wiary, tłum. A. Wilga, Wołowiec 2015, ss. 127-128.

${ }^{23}$ Słowo „mit” należy tu odczytywać w kontekście tego, jak to jest rozumiane w religiologii, czyli mit należy postrzegać jako specyficzną formę rozumienia świata, w kategoriach narracyjnych, nie zaś w kategoriach jakościowych. Zob. S. Raube, Religia na granicy mitu, „IDEA - Studia nad strukturą i rozwojem pojęć filozoficznych” 2016, XXVIII, nr 2, ss. 40-41.

${ }^{24}$ E. Panas, Element ufologiczny w Kościele scjentologicznym. Historia władcy Xenu, w: red. Kulty UFO, P. Czarnecki, A. Zaczkowska, Kraków 2014, ss. 285-286.

${ }^{25}$ Terminem „Clear” w scjentologii określa się osobę, która po przejściu serii seansów audytingu (rodzaj specyficznej rytualnej praktyki religijnej Kościoła scjentologicznego, nieco przypominająca chrześcijańską spowiedź) pozbawiła się engramów - swojego rodzaju cyst, uniemożliwiających postęp duchowy człowieka - w umyśle reaktywnym. Zob. L.D. Kliever, Scientology: Comunità di Culto, Los Angeles 1994, s. 7; I. Macut, Scijentološka „Crkva”, Zagreb 2015, ss. 83-88.

${ }^{26}$ W religii scjentologicznej pojęcie „Thetan” jest odpowiednikiem kategorii ducha, zaś terminem „Operating Thetan” określa się poziomy zaawansowania duchowego. Zob. A. Zwoliński, Scjentologia, Kraków 2007, ss. 47-49. 
lokalnym; czasem trzeba na to czekać nawet kilka lat. Jest to spowodowane między innymi tym, że przystąpienie do EPF wiąże z koniecznością zmiany miejsca zamieszkania: braniec ma się przynieść do jednego z dużych ośrodków Sea Org w Los Angeles, Clearwater, East Grinstead lub Kopenhadze.

W ramach nowicjatu rekruci pięć godzin dziennie zajmują się pracą fizyczną, kolejne pięć poświęcają studiowaniu podstaw doktryny Źródła ${ }^{27}$ - są to kursy wprowadzające w historię Sea Org, arkana technologii, etyki, a także higieny osobistej i pielęgnacji. I chociaż obecnie zdecydowana większość zakonników SO przebywa na lądzie, integralną częścią wykładów wprowadzających jest zestaw lekcji, wygłoszonych przez Komodora dla pierwszej ekipy zakonu w 1969 r. - zasady wyartykułowane dla załogi pierwszych statków są uważane za posiadające uniwersalne wartości. Estates Projecte Force nie ma wyznaczonego czasowo konkretnego okresu na zdobywanie tej wiedzy i umiejętności (zwyczajnie od parę tygodni do kilku miesięcy), bowiem jak tylko praktykant pokonuje obowiązkowe stadia procesu szkoleniowego, zalicza kurs Product Zero ${ }^{28}$ oraz pomyślnie przechodzi tzw. 7A Security Check (życiorys nie powinien mieć wzmianek o próbach samobójczych, najbliższa rodzina nie powinna mieć osób wrogo nastawionych do scjentologii), wchodzi do elitarnego gremium. Każdy rekrut oficjalnie ma mieć ukończone szesnaście lat ${ }^{29}$.

\section{Reformacja w łonie scjentologii a Organizacja Morska}

Pierwsi absolwenci „szkoły mnichów” ukończyli kurs w 1968 r., i po opuszczeniu statków zaczęli aktywnie propagować scjentologię na lądzie, zwłaszcza tam, gdzie doktryna tego NRR była wówczas jeszcze nieznana. Od 1971 r., kiedy została rozwiązana Rada Wykonawcza KS, jej obowiązki - zarządzanie krajowymi i kontynentalnymi biurami Kościoła wraz z jego ośrodkami wydawniczymi - przejęła ekipa Sea Org.

W latach 70. niemal całkiem uregulowano strefę odpowiedzialności, nad którą Sea Org sprawowała pieczę. Po pierwsze, pod jej dozór oddano jednostki szkoleniowe Saint Hill ${ }^{30}$, które specjalizują się w zaawansowanym przygotowaniu audytorów

${ }^{27}$ P. Cooper, Scandal of Scientology: A chilling examination of the nature, beliefs, and practices of the „now religion” [PDF], Gainesville 1971, s. 46.

${ }^{28}$ A. Laggia, M.P. Gardini, Byłem scjentologiem. Prawdziwe historie ludzi, którym udało się opuścić sektę, tłum. M. Szapiel, Kraków 2010, s. 36.

${ }^{29}$ T. Ortega, Scientology's Own Promotional Material Attests to 15-Year-Olds in the Sea Org, „Village Voice” 4 July 2012.

${ }^{30}$ Nazwa Saint Hill pochodzi od posiadłości w angielskim East Grinstead, w hrabstwie West Sussex, gdzie w latach 1961-1966 L. Ron czytał swoje lekcje. Tu było także miejsce pierwszego Centrum Dystrybucyjnego Kościoła Hubbarda, działającego na rzecz misji scjentologicznych, a w latach 1959-1967 mieściła się tu główna siedziba ruchu. Po renowacji w 2015 roku Saint Hill stało się muzeum, gdzie można zobaczyć prace i osiągniecia twórcy scjentologii. Zob. M. Rothstein, 
- kapłanów KS (jest to rodzaj seminariów lub uczelni wyższych). Po drugie, załoga kontroluje pracę Advanced Organisations (AO) - pracujących na zasadzie podziału geograficznego struktur, oferujących szkolenia kapłanom wyższej rangi oraz audyting stopnia OT V. Po trzecie, kadra SO oferuje najbardziej zaawansowane praktyki rozwoju duchowego, po odbyciu których się uzyskuje najwyższe stopnie $\mathrm{OT}^{31}$.

Kadra oficerska zakonu SO była obecna i bardzo aktywnie brała udział w reorganizacji Kościoła w latach 1979-1980, kiedy ruch LRH popadł w poważne tarapaty prawne w USA ${ }^{32}$. W 1979 r. Kościół scjentologiczny zaczął doświadczać traumy będącej wynikiem problemów zarówno zewnętrznych ${ }^{33}$, jak i wewnętrznych $^{34}$. Wspomniany wyżej prof. J. Gordon Melton porównuje ten trudny okres do czasu Reformacji w historii katolicyzmu ${ }^{35}$. Podobnie jak mnisi zakonów dominikańskiego i jezuickiego odegrali kluczową rolę w XVI stuleciu, podobnie kadra SO stanęła na wysokości zadania, odbijając przeróżne ataki w celu zachowania KS jako instytucji, bowiem zagrożenie głęboką schizmą było wówczas tak duże, jak nigdy dotąd. Załoga Organizacji Morskiej skupiła w swoich rękach jeszcze większą władzę niż dotychczas, sprawując pieczę nad nowo powołanymi jednostkami kościelnymi - Międzynarodowym Kościołem scjnetologicznym, który stał się organizacją-matką dla autonomicznych placówek kościelnych na całym świecie, oraz Międzynarodowymi Misjami scjentologicznymi.

Najważniejszą nową jednostką było Religijne Centrum Technologii (ang. Religious Technolgy Center, RTC), którego głównym celem było nadzorowanie ortodoksji oraz ortopraksji we wszystkich misjach i kościołach scjentologicznych. Ponadto RTC odsprzedaje licencję, umożliwiając korzystanie z materiałów, praktyk, technologii, nazw i symboli scjnetologicznych ${ }^{36}$. Powstanie tych i szeregu innych struktur polegało na całkowitej reorganizacji scjentologii wraz z przyjęciem przez członków Sea Org roli przywódczej na poziomie krajowym, kontynentalnym i międzynarodowym.

Space, Place and Religious Hardware: L. Ron Hubbard's Charismatic Authority in the Church of Scientology, w: Handbook of Scientology, red. J.R. Lewis, Leiden-Boston 2017, ss. 515-520.

${ }^{31}$ Church of Scientology Flag Service Organization, Discover New Realms of Case Gain, w: The Flag Land Base, red. Adresso Officer FSO, Tampa 2010, s. 11.

32 J. Gordon Melton, A Contemporary Ordered Religious Community..., s. 25.

${ }^{33}$ Wówczas aresztowano kilku wysoko postawionych urzędników, związanych z Biurem Strażniczym (ang. the Guardian’s Office) Kościoła, w tym żonę L. Rona, Mary Sue (1931-2002); w następnym roku aresztowani zostali skazani w sądzie federalnym za kilka przestępstw, wynikających z ich próby infiltracji i usunięcia kopii dokumentów z biur FBI oraz Urzędu Podatkowego, (IRS). Na ten temat zob. J. Reitman, Inside Scientology: The Story of America's Most Secretive Religion, Boston-New York 2011, ss. 122-124.

${ }^{34}$ Kościół Hubbarda był dotknięty poważną secesją w łonie organizacji, czego wynikiem było wyłonienie tzw. Wolnej Strefy scjnetologii. Na ten temat zob. T. Park, From the Church of Scientology to the Freezone, w: 'Cult Wars' in Historical Perspective: New and Minority Religions, red. E.V. Gallagher, London-New York 2017, ss. 152-164.

35 J. Gordon Melton, A Contemporary Ordered Religious Community..., s. 29.

${ }^{36}$ Church of Scientology International, The Command Channels of Scientology, Los Angeles 1988, s. 6. 


\section{4. Życie i reguła zakonna mnichów scjentologicznych}

Symbolem wiecznego przywiązania mnichów do nauki Mistrza są kontrakty, które podpisują członkowie zakonu. 18-punktowa deklaracja „Code of a Sea Org Member”, odczytywana zdanie po zdaniu, a później sygnowana przez nowicjusza, jest podpisywana na miliard lat, co oznacza wieczne zobowiązanie się do realizacji celów, potrzeb i zasad tej religii ${ }^{37}$; chętni do służby mogą też podpisać dwu- lub pięcioletnie kontrakty ${ }^{38}$. Wedle oficjalnych komunikatów Kościoła, jest to podobne do ślubów lub długoterminowej przysięgi, składanych w innych wyznaniach i zakonach, ma wymiar symboliczny ${ }^{39}$. Scjentolodzy wierzą, iż po śmierci człowieka duch nie umiera, lecz powraca, aby znaleźć sobie nowe ciało. Thetan, który podpisał kontrakt, ma więc powrócić znów do swoich obowiązków w gronie Sea Org, dlatego tuż po śmierci dostaje się 20-letni okres zwolnienia z obowiązującej umowy, aby ten czas poświęcić na powrót na ziemię i poszukiwanie nowej powłoki ${ }^{40}$. Do powrotu nawiązuje łacińskie motto Revenimus, umieszczone w emblemacie zakonu $^{41}$. Coroczna ceremonia zaprzysiężenia odbywa się 12 sierpnia, w rocznicę erygowania fraterni.

W 1975 r. na lądzie, we florydzkim Clearwater, powstała Flag Land Base, gdzie obecnie mieści się światowe centrum duchowe organizacji scjentologicznej. Sercem Sea Org pozostaje jednak 9,780-tonowy statek scjentologicznej Usługowej organizacji Okręt Flagowy FSSO „Freewinds”42, a cała załoga należy do zakonu. Ekipa Organizacji Morskiej prowadzi życie wspólnotowe, mając komunię mieszkania, wyżywienia, umundurowania, opieki medycznej, transportu oraz wszelkich kosztów związanych z egzystencją swoich członków ${ }^{43}$. Przedstawicielom zakonu na zakup przedmiotów osobistych wydaje się niewielki zasiłek, uzależniony od ich statystyk, inne zaś wydatki są pokrywane przez Kościół.

W niedzielę większość członków uczestniczy w cotygodniowych nabożeństwach, a następnie pracuje na półdziennej zmianie (mnisi mogą brać wolne co drugą niedzielę). Resztę dnia przeznaczają na osobiste potrzeby, takie jak zakupy,

37 J. Gordon Melton, A Contemporary Ordered Religious Community: The Sea Organization, w: New Religious Movements and Religious Liberty in America, red. D. Davis, B. Hankins, Waco 2003, ss. 51-52.

38 A. Zwoliński, Scjentologia, s. 114.

${ }^{39}$ L. Wright, Droga do wyzwolenia..., s. 132.

${ }^{40}$ J. Miscavige Hill, Ofiarowana. Moje życie w sekcie scjentologów, tłum. M. Filipczuk, M. Filipczuk, Kraków 2013, s. 156.

${ }^{41}$ Church of Scientology International, Welcome to the Sea Org Course. Sea Organization Product Zero, Los Angeles 1990, s. i.

${ }^{42}$ L. Ron Hubbard Library, The L. Ron Hubbard Series - Master Mariner..., ss. 196-207.

43 Я.Ф. Трофимов, Церковь Саентологии. Опыт религиоведческого анализа, Алматы 2006, s. 37. 
czyszczenie ich osobistej przestrzeni i pranie ubrań. Zakon Organizacji Morskiej kupuje zniszczone nieruchomości i je odnawia, a prace renowacyjne, zwykle wiążące się z pewną formą wysiłku fizycznego, takiego jak: układanie cegieł, instalowanie kanalizacji lub gniazdek elektrycznych, sadzenie krzewów lub malowaniw ścian, wykonują członkowie fraterni SO.

Zakonników nie obowiązuje celibat, śluby są jednak dozwolone wyłącznie wewnątrz Sea Org ${ }^{44}$, aczkolwiek nie jest dozwolone posiadanie dzieci ${ }^{45}$. Jeżeli wstępując do Organizacji, ktoś już posiadał potomstwo, musiał je czasowo oddelegować do specjalnej jednostki Cadet Org ${ }^{46}$, która się nim opiekowała do ukończenia przez nie sześciu lat, po czym było ono kierowane - już jako kadeci - do Organizacji Posłańców Komodora, rzadko jednak widując się z rodzicami ${ }^{47}$; po 1986 r. Cadet Org została rozwiązana ${ }^{48}$. Wedle relacji byłych członków, obecnie w razie zajścia kobiety w ciążę, Kościół przenosi ją albo parę do placówki niższej rangi do momentu osiągnięcia przez dziecko pełnoletności (jest to swego rodzaju urlop rodzicielski $)^{49}$, albo, wedle krytyków scjentologii, zmusza do aborcji ${ }^{50}$.

Sami przedstawiciele KS nie uznają tego typu zarzutów, powołując się na teksty Dianetyki, gdzie stwierdza się, że aborcja powoduje aberrację ${ }^{51}$. Ponadto nie ma pewności, czy płód w łonie kobiety nie został już uprzednio wybrany przez jakiegoś Thetana, aborcja więc byłaby działaniem godzącym w etykę ${ }^{52}$. Ciekawe w związku z tym wydaje się oświadczenie syna LRH Rona Hubbarda Jr. - obecnie zmienił swoje imię na Ronald DeWolf - opowiadającego o tym, iż urodził się dwa miesiące wcześniej, co prawdopodobnie, wedle jego słów, mogło być spowodowane właśnie nieudaną aborcją, przeprowadzoną przez Hubbarda Seniora ${ }^{53}$. Biorąc pod uwagę charakter Kościoła, gdyby to rzeczywiście kiedykolwiek stało się polityką Organizacji Morskiej, niewątpliwie zostałby papierowy stos dokumentów, które jednak, jak na razie, nigdy nie zostały odnalezione lub upublicznione.

${ }^{44}$ Małżeństwo jako jeden z sakramentów w kulcie Rona pełni funkcje sakralne, więc zasadniczo taki związek implikuje endogamię. Zob. M. Zimniak-Hałajko, Raj oswojony. Antropologia nowych ruchów religijnych, Gdańsk 2003, s. 226.

${ }_{45}$ Tę praktykę wprowadził po śmierci Hubbarda w 1986 r. dyrektor wykonawczy G. Leserve. Zob. L. Wright, Droga do wyzwolenia..., s. 269.

${ }^{46}$ B. Kiddo, Devoted to the Cult. Book 1: An Orphan with Parents [eBook], b.m.w. 2008, ss. $15-16$.

${ }^{47}$ A. Zwoliński, Sekty w ekonomii, „Cywilizacja” 2002, nr 3, s. 300.

${ }^{48}$ Ex-Scientology Kids, Sea Org?, http://exscientologykids.com/sea-org-2/ [dostęp: 15.10. 2017].

49 A. Morton, Tom Cruise: An Unauthorized Biography, New York 2008, s. 130.

${ }^{50}$ S.A. Kent, Scientology - Is this a Religion?, „Marburg Journal of Religion” 1999, vol. 4, nr 1, s. 10.

${ }^{51}$ L. Ron Hubbard, Dianetyka: Współczesna nauka o zdrowiu umysłowym, Glostrup 2009, s. 161.

52 L. Ron Hubbard, Scjentologia. Nowe spojrzenie na życie, Glostrup 2009, ss. 238-239.

${ }_{53}$ M. Górna, Głowa Kościoła scjentologicznego zleciła szpiegowanie własnego ojca: „Jeśli dostanie zawału, pozwólcie mu umrzeć”, „Gazeta Wyborcza” z 9 kwietnia 2015 r. 


\section{Rehabilitation Project Force. Restrykcje i kontrowersje wokół Organizacji Morskiej}

Członkowie zakonu są objęci nakazem milczenia odnośnie do tego, co robią, co jedzą, w jakich warunkach śpią ${ }^{54}$. Kolektyw fraterni obowiązują dosyć restrykcyjne i twarde prawidła: surowa dyscyplina, bezwzględne posłuszeństwo i zgodność, kontrola bezpieczeństwa przez kościelne Komisję Śledczą i Komitet Ewidencji, długie godziny pracy (blisko 100 godzin tygodniowo, jeden dzień wolny na dwa tygodnie), komunalne mieszkania, zakaz używania narkotyków, uprawiania seksu pozamałżeńskiego ${ }^{55}$. Należy jednak wspomnieć, że istnieje również system odwoławczy, w wyniku którego osoby uważające, iż wstępne ustalenia przeciwko nim były błędne, mogą dochodzić zadośćuczynienia.

Według relacji eks-członków zakonu, kary za przewinienia lub zaniedbania są zaiste drakońskie: noszenie łańcuchów, zamykanie pod pokładem, mizerny posiłek z ryżu i fasoli ${ }^{56}$ lub resztek jedzenia ${ }^{57}$; ci zaś, którzy zasłużyli na największą dezaprobatę, lądowali w morzu ze związanymi rękoma i opaską na oczach ${ }^{58}$. Najwięcej zastrzeżeń budzi Rehabilitation Project Force (RPF), powstały w 1974 r. program resocjalizacyjny, przeznaczony do izolowania i rehabilitacji tych, którzy nie spełnili oczekiwań Sea Org, nie poddali się kontroli bezpieczeństwa bądź złamali ustalone zasady, lecz nadal chcieli pozostać w zakonie ${ }^{59}$. RPF, czyli „najwyższy gradient etyki scjentologicznej”60, składa się na ośmiogodzinną fizyczną pracę sześć dni w tygodniu, dodatkowo pięć trzeba poświęcić na studiowanie Pism lub audytowanie.

Są opinie, że używane w RPF praktyki mogą kwalifikować Sea Org jako formację paramilitarną ${ }^{61}$, a stosowane w obozie metody jako psychologicznie niszczące i brutalne, RPF jest więc rodzajem „prania mózgu”62, mimo że w naukach społecznych toczą się zażarte dyskusje o istnieniu tego zjawiska „reformy myśli”

${ }^{54}$ A. Laggia, M.P. Gardini, Byłem scjentologiem..., ss. 38-39, 60.

${ }^{55}$ B. Kiddo, Devoted to the Cult. Book 1..., s. 29.

56 J. Atack, A Piece of Blue Sky..., s. 242.

${ }^{57}$ N. Many, My Billion Year Contract: Memoir of a Former Scientologist, Los Angeles 2009, s. 91.

58 J. Ritchie, Tajemniczy świat sekt i kultów, tłum. I. Bajer, Warszawa 1994, s. 114; L. Wright, Droga do wyzwolenia..., s. 153.

${ }^{59}$ RPF został wymyślony w celu zastąpienia praktyki tzw. Brygad błotnych skrzyń (ang. Mud Box Brigade). Za niewykonanie bądź nieprawidłowe wykonanie przydzielonych zadań członkowie załogi za karę mieli oczyszczać na statkach zęzę, czyli miejsce wewnątrz kadłuba statku, gdzie zbierało się błoto z kotwic, brudna woda oraz wszelkie nieczystości (rozlane paliwo, smary czy różne śmieci).

${ }^{60}$ A. Laggia, M.P. Gardini, Byłem scjentologiem..., s. 44.

${ }^{61}$ E. Townsend, The Sad Tale of Scientology..., s. 78; A. Zwoliński, Scjentologia, s. 131; G. Rowiński, M. Purzycka, Inne niebo, czy w sieci szalonego proroka: nowe ruchy i sekty religijne w Polsce, Warszawa 1998, s. 58.

${ }^{62}$ H.B. Urban, The Church of Scientology..., s. 126. 
jako takiego ${ }^{63}$. Główne zarzuty, wysuwane wobec koncepcji RPF, zawierają kilka pozycji: przymusowe prace i utrzymywanie $\mathrm{w}$ zamknięciu ${ }^{64}$, fizyczne znęcanie się $^{65}$ i słaba dieta ${ }^{66}$, poniżenie społeczne przez zakaz utrzymywania stosunków i ograniczenie korespondencji ${ }^{67}$, wymuszone „spowiedzi” ${ }^{\prime 8}$ wbrew nakazowi LRH o niestosowaniu audytowania osób tego sobie nieżyczących ${ }^{69}$. W latach 50 . ubiegłego stulecia pojawiła się broszura o technikach manipulacji w totalitarnych systemach na przykładzie ZSRR. Autor - są opinie, że jest nim nie kto inny, jak tylko sam L. Ron ${ }^{70}$ - opisuje różne techniki, które przypominają właśnie te stosowane później wobec korpusu Sea Org ${ }^{71}$. Omawiane są tu sposoby działania skutkujące tym, że cele jednostki pokrywają się z celami grupy ${ }^{72}$.

Krytyka RPF jest zasadniczo skonstruowana na podstawie informacji uzyskanej od byłych członków KS, którzy odeszli z szeregów organizacji. Taka narracja częstokroć bywa mieszana z opisem praktyk z okresu formacyjnego z nowszym przekazem, kiedy to nadużycia mają charakter incydentalny, nie zaś esencjalny ${ }^{73}$.

Należy jednak zwrócić uwagę, że nawet eks-członkowie organizacji postrzegają przynależność do zakonu jako realizację marzeń, ponieważ już same przebywanie na statku obok Komodora, kiedy ten jeszcze żył, sprawiało wielką przyjemność i zaszczyt ${ }^{74}$. Badacze zjawiska alternatywnej i nowej religijności oceniając RPF, dochodzą więc do diametralnie różnych wyników - czy wspomniana praktyka jest dobrowolna lub przymusowa, ma charakter terapeutyczny lub raczej ściśle karny ${ }^{75}$. Są opinie, że życie wspólnotowe w szeregach Sea Org wraz z jej praktykami odpowiada życiu w tradycyjnych zakonach religijnych, tych na Wschodzie i na Zachodzie ${ }^{76}$.

${ }^{63}$ L. Wright, Droga do wyzwolenia..., s. 195.

${ }^{64}$ M. Pignotti, My Nine Lives in Scientology, b.m.w. 1989, s. 10.

${ }^{65}$ M. Rathbun, The Scientology Reformation: What Every Scientologist Should Know [PDF], Scotts Valley 2012, s. 61.

${ }^{66}$ M. Rybarczyk, Scjentologia-kościół strachu, „Newsweek Polska” nr 26 z 24-30 czerwca 2013 r., s. 75.

67 J. Atack, A Piece of Blue Sky..., s. 161.

${ }^{68}$ S.A. Kent, Brainwashing in Scientology's Rehabilitation Project Force (RPF), Hamburg 2000, s. 15.

69 J. Miscavige Hill, Ofiarowana..., s. 402.

${ }^{70}$ M. Introvigne, Does Scientology Believe in Brainwashing? The Strange Story of the Brain-Washing Manual of 1955 [PDF], Antwerpen 2014, ss. 2, 28. Sam Hubbard później wyjaśniał, że autorem jest niejaki Paul Fadkeller, który w 1947 r. wydał tę broszurę w Berlinie.

${ }^{71}$ L. Ron Hubbard (?), Brain-washing: A Synthesis of the Russian Text Book on Psychopolitics [reprint 1959], red. Ch. Stickley, Washington 1982, ss. 42-45.

${ }^{72}$ L. Wright, Droga do wyzwolenia..., s. 201.

${ }^{73}$ Na ten temat zob. J. Gordon Melton, A Contemporary Ordered Religious Community..., w: New Religious Movements..., ss. 46-54.

${ }^{74}$ M. Pignotti, My Nine Lives..., s. 21.

75 D.E. Cowan, D.G. Bromley, The Church of Scientology, w: Introduction to New and Alternative Religions in America. Volume 5: African Diaspora Traditions and Other American Innovations, red. E.V. Gallagher, W. Michael Ashcraft, Westport-London 2006, s. 182.

${ }^{76}$ F.K. Flinn, II. The Sea Organization and Its Role within the Churc of Scientology. Religious Orders, East and West, w: Decaration of Frank K. Flinn in support of defendants'joint motion 
Wytyczne Kościoła przewidują ewentualną możliwość wystąpienia z fraterni. W najbardziej ekstremalnych przypadkach, gdy członek Organizacji Morskiej stracił wiarę w scjentologię, aktywnie podjął się działań mających na celu zaszkodzenie Kościołowi lub nie ma ochoty na dalsze przebywanie w szeregach wiernych, Komisja może zalecić wydalenie takiej osoby z grona SO, a nawet Kościoła. Wówczas taka osoba dostaje tzw. rachunek darmozjada, rozliczający na mocy wstecznej wszystkie świadczone mu usługi, czynności, szkolenia. Dopóki eks-zakonnik nie wpłaci całej sumy, jest obciążony swego rodzaju ekskomuniką. Procedura opuszczenia, w żargonie LRH Good standing, przewiduje wypełnienie obiegówki o nazwie Routing form, kwestionariusza z wytłumaczeniem powodów odejścia. Dalej następuje audyting i kontrola bezpieczeństwa według zasad etycznych.

Proces opuszczania Sea Org może zająć nawet kilka miesięcy ${ }^{77}$. Znane są przypadki, kiedy osoby wyrzucone z Kościoła przeszły na długoterminową publiczną opozycję wobec scjentologii. Osoba „ekskomunikowana” zostaje odcięta od wszystkich świadczeń dostępnych członkom Kościoła, jak to bywa w innych systemach religijnych.

\section{Symbolika Organizacji Morskiej}

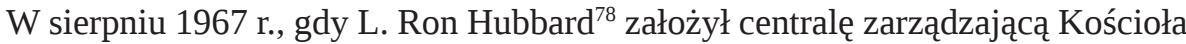
scjentologicznego, zostało przygotowane również logo jednostki - znakiem rozpoznawczym nowej organizacji kościelnej stała się otoczona dwiema gałązkami laurowymi gwiazda-pentagram, symbol poziomu OT III, sięgający korzeniami sygnatury Galaktycznej Konfederacji, która istniała 75 mln lat temu ${ }^{79}$. Laur w tych zamierzchłych czasach rzekomo miał oznaczać szeroko pojęte zwycięstwo, gwiazda była metaforą ducha, pragnącego powrócić do źródła, połączenie tychże części natomiast sugerowało tryumf tak szlachetnego celu Thetana. Kolor tego emblematu wobec tego ma być zawsze złoty i umieszczony w niebieskim tle, symbolizującym

for partial summary judgment, Headley v. Church of Scientology International, Case No. CV 09-3987 DSF (MANx), 5 August 2010, ss. 5-14; J. Gordon Melton, A Contemporary Ordered Religious Community..., ss. 56-57, 60.

77 M.P. Gardini, Byłam scjentologiem. Rozmowa z Albertem Laggiq, tłum. K. Kozak, Radom 2008, s. 117.

${ }^{78}$ Akurat wówczas Lafayette Hubbard mianuje siebie Komodorem floty czterech scjentologicznych statków, które tworzyły eskadrę Kościoła. Kiedyś te statki były kwaterę główną organizacji byłego oficera marynarki USA. Zob. L. Wright, Droga do wyzwolenia..., s. 133.

${ }^{79}$ J. Atack, A Piece of Blue Sky..., s. 29; R. Woodstock, Scientology and UFOs, w: Inside Scientology. The story of America’s Most Secretive Religions, „Vision Report Watch” 2012, nr 21, s. 16. 
prawdę $^{80}$. Dwie gałązki laurowe w sumie mają dwadzieścia sześć liści ${ }^{81}$ - jest to nawiązanie do podobnej liczby gwiazd w składzie Konfederacji ${ }^{82}$.

Opisane insygnia OT III, a zarazem znaku rozpoznawczego personelu Sea Org stanowią część większego godła tejże organizacji, gdzie, oprócz wspomnianych już gwiazdy oraz liści laurowych, w herbie są umieszczone krzyż scjentologiczny, dwa koniki morskie i unoszące się w górę trzy mewy ${ }^{83}$. Białe ptaki są symbolem uwolnienia się ducha, biały kolor oznacza jego czystość, podczas gdy liczba trzy jest wyrazem takich podstawowych koncepcji LRH, jak Trzecia Dynamika ${ }^{84}$, cykl działania stworzenie-przeżycie-zniszczenie ${ }^{85}$, kondycje istnienia być-robić-mieć ${ }^{86}$; konik morski, będący symbolem audytora VIII klasy, oznacza ciągłe poświęcenie się organizacji dla utrzymywania standardowej technologii Mistrza ${ }^{87}$. Stopnie powyżej VIII klasy uzyskuje się tylko, będąc członkiem Sea Org. Wówczas audytor ma w swoim godle symbole wieńca, gwiazdy, dwóch koników morskich oraz znak OT, wpisany w trójkąt dianetyki ${ }^{88}$. Oprócz opisanych detali logo Organizacji Morskiej zawiera jeszcze motto Revenimus ${ }^{89}$ (łac. powracamy), napisane na jednej z czterech wstążek w kolorze czerwonym (pozostałe trzy są w kolorze złota) ${ }^{90}$; jest ono zwykle umieszczane na umowie, podpisywanej przez osoby chętne do wejścia do tej elitarnej i uprzywilejowanej komórki Kościoła ${ }^{91}$.

Autorzy zajmujący się studium nad scjentologią, w swoich pracach dość sceptycznie odnoszą się do oryginalności emblematyki, wykorzystywanej przez Kościół Hubbarda. Główną przyczyną tego nieprzychylnego nastawienia jest rzekome zapożyczenie przez Rona wielu znaków i symboli o charakterze okultystycz-

${ }^{80}$ L. Ron Hubbard, Sea Org Symbol, w: Modern Management Technology Defined. Shortened version, contains only the definitions, red. Church of Scientology of California, Los Angeles 1976, s. 583.

${ }^{81}$ L. Ron Hubbard Library, The L. Ron Hubbard Series - Master Mariner..., s. 198.

${ }^{82}$ L. Wright, Droga do wyzwolenia..., s. 450.

${ }^{83}$ Church of Scientology International, Welcome to the Sea Org Course..., s. i.

${ }^{84}$ L. Ron Hubbard, Dynamiki istnienia, Copenhagen 2006, s. 11.

${ }^{85}$ L. Ron Hubbard, The Creation of Human Ability - A Handbook for Scientologists, Copenhagen 2007, s. 28.

${ }^{86}$ L. Ron Hubbard, Scjentologia. Podstawy myśli - Podstawowa ksiq̨żka o teorii i praktyce Scjentologii dla poczq̨tkujq̨cych, Glostrup 2009, ss. 31, 121.

${ }^{87}$ Klasa VIII jest najwyższym stopniem, możliwym do uzyskania przez nie-członków Sea Org. Zob. L. Ron Hubbard, Missionaire First Class, w: Modern Management Technology Defined..., red. Church of Scientology of California, s. 421.

${ }^{88}$ Church of Scientology International, The Classification Chart: Auditor Training Services. Level IX-XII - Class IX-XII Auditor, http://www.whatisscientology.org/html/Part03/Chp14/ pg0264.html [20.01.2016].

89 J. Miscavige Hill, Ofiarowana..., s. 10.

90 P. Coulter, E.D. Ziff, M.S. Hubbard, The History and Symbology of the Sea Org Coat of Arms, „Flag Order” nr 3350, 24 June 1973, s. 1, 4.

${ }^{91}$ Church of Scientology International, Sea Organization Religious Commitment, Los Angeles 2002, s. 1. 
nym, przede wszystkim z systemu spirytualistycznego brytyjskiego magika, poza tym satanisty, Aleistera Crowleya, oraz semiotyki różokrzyżowców. Rosyjski teolog prawosławny Aleksandr Dvorkin, zajmujący się nowymi ruchami religijnymi, zauważa w swojej pracy, iż scjentologiczny znak ma korzenie w magii ${ }^{92}$, upatrując w tym symbolu krzyż z odwrotu kart Tarota Księgi Thotha autorstwa Crowleya ${ }^{93}$. Zaadoptowany przez Hermetyczny Zakon Złotego Świtu (inna nazwa - Złotego Brzasku), a później i przez Aleistera Crowley’a, ów emblemat pochodzi wprost od różokrzyżowców ${ }^{94}$. W opisie krzyża swojego Kościoła L. Ron powołuje się na etymologię tego słowa, wywodząc ją od „światła Wielkiego Ognia”95. Ciekawy wydaje się być właśnie ten fakt, że akurat dokładnie takie same sformułowanie jest zawarte w tekście Tablica Szmaragdowa Hermesa Trismegistosa ${ }^{96}$, hermetycznym dziele, do którego odwoływali się alchemicy, adepci nauk okultystycznych, ezoterycy i różokrzyżowcy. Budowa krzyża LRH ma wyraźne podobieństwo ze znakiem hermetyków, choć różnią się one kolorystycznie oraz wymiarowo.

Powiązanie założyciela scjentologii z magią przypuszczalnie można wytłumaczyć kontaktami młodego Rona Hubbarda w latach 30.-40. XX wieku z amerykańskim chemikiem Jackiem Parsonsem ${ }^{97}$, z którym obaj panowie wtedy działali w loży Agapé Ordo Templi Orientis ${ }^{98}$, międzynarodowej organizacji religijno-zakonnej o charakterze paramasońskim, której najbardziej znanym członkiem był przywoływany już Crowley ${ }^{99}$, którego Hubbard podczas jednego ze swoich wykładów nazwie „my very good friend”100.

Scjentologiczna koncepcja istnienia zawiera tezę o stałym i odruchowym poszukiwaniu przyjemności, której najwyższą formą jest nieskończoność przeżycia lub też nieśmiertelność. Dlatego podążanie wszelkich istot żywych ku wieczności

92 А.Л. Дворкин, Сектоведение. Тоталитарные секты. Опыт систематического исследования, Нижний Новгород 2014, s. 202.

93 A. Crowley, The Book of Thoth (Egyptian Tarot), York 1995, ss. 76-79, 206, 215-216; G. Ziegler, Tarot: Mirror of the Soul. Handbook for the Aleister Crowley Tarot, York 1991, ss. 21-22, 143, 167.

${ }^{94}$ P.F. Case, True and Invisible Rosicrucian Order: An Interpretation of the Rosicrucian Allegory and An Explanation of the Ten Rosicrucian Grades, Boston-York 1989, ss. 133-142.

${ }_{95}$ L. Ron Hubbard, Cross, w: Modern Management Technology Defined..., red. Church of Scientology of California, s. 153.

${ }^{96}$ N. Goodrick-Clarke, The Western Esoteric Traditions: A Historical Introduction, New York 2008, ss. 17-18.

${ }^{97}$ H.B. Urban, The Occult Roots of Scientology? L. Ron Hubbard, Aleister Crowley, and the Origins of a Controversial New Religion, „Nova Religio: The Journal of Alternative and Emergent Religion” 2012, vol. 15, nr 3, ss. 94-95, 98-99.

${ }_{98}$ R.E. Guelley, The Encyclopedia of Magic and Alchemy, New York 2006, ss. 232-233.

${ }_{99}$ G.A. Mather, L.A. Nichols, Słownik sekt, nowych ruchów religijnych i okultyzmu, tłum. A. Czwojdrak, Warszawa 2006, ss. 386-387.

${ }^{100}$ L. Ron Hubbard, Conditions of Space/Time/Energy. A Lecture given by L. Ron Hubbard on the 5. December 1952, w: Philadelphia Doctorate Course PDC, red. Ron's Org Grenchen, Grenchen 2010, s. 298; J. Atack, A Piece of Blue Sky..., s. 70. 
jest podstawowym elementem egzystencji każdego organizmu ${ }^{101}$. Znak nieskończoności, lemniskata, w kształcie przewróconej ósemki, wyraża wiarę scjentologów w tę zasadę. Ów symbol pojawia się często w oprawie graficznej dzieł L. Rona i może występować tak, nakładając się na trójkąty, jak również być umiejscowiony $\mathrm{w}$ granicach tychże figur ${ }^{102}$.

\section{Podsumowanie. Organizacja Morska u progu XXI wieku}

Fenomen Organizacji Morskiej oferuje badaczom nowych religii ewentualną możliwość zrozumienia tego, w jaki sposób NRR wpisują się w ponowoczesny obraz życia religijnego i kulturę codzienności. Bliższe przejrzenie się zasadom i regułom tej grupy pozwala na wnioskowanie o podobieństwie korpusu SO do organizacji i wspólnot o podobnej proweniencji. Próba zbadania uporządkowanych społeczności wiernych, do których niewątpliwie należy zaliczyć Organizację Morską, pomaga również podczas wyjaśnienia niektórych zjawisk osobistego zaangażowania się członków niektórych grup w religijne praktyki swojej konfesji.

Obecnie gremium zakonu SO pełni przeróżne funkcje ${ }^{103}$, prowadząc nie tylko zaawansowane seanse audytingu, lecz też przyczyniając się do wielu czynności, zwłaszcza z zakresu społecznej nauki swojego Kościoła. Pragnieniem oficerów Organizacji Morskiej jest „odclearowanie planety”104. Może to być jakiś element poglądów Jiddu Krishnamuriego, w dziełach którego jest zachęta do odkrywania własnych ograniczeń w celu osiągnięcia całkowitej wolności duchowej i psychologicznej ${ }^{105}$.

Dzisiaj owa formacja zakonna, zachowując swoją historyczną nazwę, liczy około pięciu tysięcy członków (od początku lat 70. XX wieku liczba mnichów zwiększyła się dziesięciokrotnie), każdy z nich jest Clearem, ma stopień OT ${ }^{106}$. Zdecydowana większość z nich od 1975 r. stale przebywa na lądzie ${ }^{107}$, nadal zaś mają mundury w charakterystycznym morskim stylu oraz stopnie i tytuły marynarki ${ }^{108}$, a do każdego z nich bez względu na płeć należy zwracać się per „sir”109.

${ }^{101}$ L. Ron Hubbard, Scjentologia. Nowe spojrzenie..., s. 60.

102 Church of Scientology International, Dianetics \& Scientology: Materials by L. Ron Hubbard, Los Angeles 2010, s. 74, 78; L. Ron Hubbard, Dynamiki istnienia, ss. 20-21.

${ }_{103}$ Sea Organization Success Denny Chang [ulotka propagandowa Sea Org], 2011.

${ }^{104}$ M. Pignotti, My Nine Lives..., s. 16.

105 L. Wright, Droga do wyzwolenia..., s. 253.

${ }^{106}$ Church of Scientology International, What is Scientology? The Comprehensive Reference..., s. 423.

107 D. de Chant, D.L. Jorgensen, The Church of Scientology..., s. 225.

${ }^{108}$ Church of Scientology International, What Is the Sea Organization?, http://www.scientology.org/faq/church-management/what-is-the-sea-organization.html [11.04.2016]. Pełną listę stopni i tytułów kadry Sea Org zob. D. Westbrook, Among the Scientologists: History, Theology, and Praxis, New York 2018, s. 142.

109 Por. J. Reitman, Inside Scientology..., s. 82. 
Największe skupiska członków Sea Org znajdują się w Los Angeles, Clearwater, Kopenhadze, Londynie, Saint Hill, Sydney, mniejsze koncentracje są zwykle w Ideal Orgs ${ }^{110}$ Europy, Kanady, Stanów Zjednoczonych i RPA ${ }^{111}$. Ostatnie doniesienia świadczą o tym, że lider Kościoła Miscavige już w obrębie istniejącej Sea Org stworzył SEALs - nowy elitarny pododdział, członkowie którego otrzymują nieco lepsze świadczenia i zaopatrzenie ${ }^{112}$.

Członkowie Organizacji Morskiej - a jest to stosunkowo niewielka liczba członków Kościoła scjentologicznego - stanowią jednak trzon elitarny związku wyznaniowego, poświęcając swoje życie na wspieranie i rozwój religijny misji scjentologicznych na wszystkich kontynentach, gdzie ów nowy ruch religijny jest obecny. Wypełniając swoje duchowe powołanie, angażując się coraz bardziej na rzecz krzewienia wiary i nauk swojego założyciela, scjentolodzy są przekonani co do słuszności i szlachetności swojej misji duchowej, gdyż zmieniając ten świat, robią go lepszym, doskonalszym i bardziej koherentnym.

\section{Literatura}

Atack J., A Piece of Blue Sky: Scientology, Dianetics and L. Ron Hubbard Exposed, New York 1990.

Bainbridge W.S., The Endtime Family: Children of God, New York 2002.

Case P.F., True and Invisible Rosicrucian Order: An Interpretation of the Rosicrucian Allegory and An Explanation of the Ten Rosicrucian Grades, Boston-York 1989.

Chant D. de, Jorgensen D.L., The Church of Scientology: A Very New American Religion, w: World religions in America: an introduction, red. J. Neusner, Louisville 2003.

Church of Scientology Flag Service Organization, Discover New Realms of Case Gain, w: The Flag Land Base, red. Adresso Officer FSO, Tampa 2010.

Church of Scientology International, Dianetics \& Scientology: Materials by L. Ron Hubbard, Los Angeles 2010.

Church of Scientology International, Meeting the Global Demand for the Scientology Religion, w: „Freedom”. Investigative Reporting in the Public Interest, Tampa 2009.

Church of Scientology International, Sea Organization Religious Commitment, Los Angeles 2002.

Church of Scientology International, The Classification Chart: Auditor Training Services. Level IX-XII - Class IX-XII Auditor, http://www.whatisscientology.org/html/Part03/ Chp14/pg0264.html [dostęp: 20.01.2016].

Church of Scientology International, The Command Channels of Scientology, Los Angeles 1988.

${ }^{110}$ Ideal Org - rodzaj placówki kościelnej, jeden z najwyższych szczebli w eklezjologii scjentologicznej. Zob. L. Ron Hubbard, Delivery, „The Auditor” 1970, nr 59, s. 1; Church of Scientology International, Meeting the Global Demand for the Scientology Religion, w: „Freedom”. Investigative Reporting in the Public Interest, Tampa 2009, s. 13; M. Rathbun, The Scientology Reformation..., s. 37.

111 J. Gordon Melton, A Contemporary Ordered Religious Community..., s. 49.

112 A. Morton, Tom Cruise..., s. 136. 
Church of Scientology International, Welcome to the Sea Org Course. Sea Organization Product Zero, Los Angeles 1990.

Church of Scientology International, What is Scientology? The Comprehensive Reference on the World's Fastest Growing Religion, Los Angeles 1998.

Church of Scientology International, What Is the Sea Organization?, http://www.scientology. org/faq/church-management/what-is-the-sea-organization.html [11.04.2016].

Ciż, New Monasticism: An Interspiritual Manifesto for Contemplative Life in the 21st Century, „Kosmos” Spring | Summer 2013.

Cooper P., Scandal of Scientology: A chilling examination of the nature, beliefs, and practices of the „now religion” [PDF], Gainesville 1971.

Coulter P., Ziff E.D., Hubbard M.S., The History and Symbology of the Sea Org Coat of Arms, „Flag Order” nr 3350, 24 June 1973.

Cowan D.E., Bromley D.G., The Church of Scientology, w: Introduction to New and Alternative Religions in America. Volume 5: African Diaspora Traditions and Other American Innovations, red. E.V. Gallagher, W. Michael Ashcraft, Westport-London 2006.

Crowley A., The Book of Thoth (Egyptian Tarot), York 1995.

Ex-Scientology Kids, Sea Org?, http://exscientologykids.com/sea-org-2/ [dostęp: 15.10.2017].

Flinn F.K., II. The Sea Organization and Its Role within the Churc of Scientology. Religious Orders, East and West, w: Decaration of Frank K. Flinn in support of defendants'joint motion for partial summary judgment, Headley v. Church of Scientology International, Case No. CV 09-3987 DSF (MANx), 5 August 2010.

Flinn F.K., Scientology: The Marks of Religion, w: Scientology: Theology and Practice of a Contemporary Religion, red. Church of Scientology International, Los Angeles 1999.

Gardini M.P., Byłam scjentologiem. Rozmowa z Albertem Laggiq, tłum. K. Kozak, Radom 2008.

Goodrick-Clarke N., The Western Esoteric Traditions: A Historical Introduction, New York 2008.

Gordon Melton J., A Contemporary Ordered Religious Community: The Sea Organisation, „The Journal of CESNUR” 2018, vol. 2, nr 2.

Gordon Melton J., A Contemporary Ordered Religious Community: The Sea Organization, w: New Religious Movements and Religious Liberty in America, red. D. Davis, B. Hankins, Waco 2003.

Gordon Melton J., Birth of a Religion, w: Scientology, red. J.R. Lewis, Oxford 2009.

Górna M., Głowa Kościoła scjentologicznego zleciła szpiegowanie własnego ojca: „Jeśli dostanie zawału, pozwólcie mu umrzeć”, „Gazeta Wyborcza” z 9 kwietnia 2015 r.

Guelley R.E., The Encyclopedia of Magic and Alchemy, New York 2006.

Introvigne M., Does Scientology Believe in Brainwashing? The Strange Story of the Brain-Washing Manual of 1955 [PDF], Antwerpen 2014.

Kent S.A., Brainwashing in Scientology's Rehabilitation Project Force (RPF), Hamburg 2000.

Kent S.A., Scientology - Is this a Religion?, „Marburg Journal of Religion” 1999, vol. 4, nr 1.

Kiddo B., Devoted to the Cult. Book 1: An Orphan with Parents [eBook], b.m.w. 2008.

Kliever L.D., Scientology: Comunità di Culto, Los Angeles 1994.

Laggia A., Gardini M.P., Byłem scjentologiem. Prawdziwe historie ludzi, którym udało się opuścić sektę, tłum. M. Szapiel, Kraków 2010.

Lewis J.R., Introduction, w: Scientology, red. J.R. Lewis, Oxford 2009. 
Macut I., Scijentološka „Crkva”, Zagreb 2015.

Many N., My Billion Year Contract: Memoir of a Former Scientologist, Los Angeles 2009.

Mather G.A., Nichols L.A., Słownik sekt, nowych ruchów religijnych i okultyzmu, tłum.

A. Czwojdrak, Warszawa 2006.

McEntee R., Bucko A., New Monasticism: An Interspiritual Manifesto for Contemplative Life in the 21st Century, „Kosmos” Spring | Summer 2013

McEntee R., Bucko A., New Monasticism: An Interspiritual Manifesto for Contemplative Life in the 21st Century, New York 2015.

Miscavige Hill J., Ofiarowana. Moje życie w sekcie scjentologów, tłum. M. Filipczuk, M. Filipczuk, Kraków 2013.

Morton A., Tom Cruise: An Unauthorized Biography, New York 2008.

Ortega T., Scientology's Own Promotional Material Attests to 15-Year-Olds in the Sea Org, „Village Voice” 4 July 2012.

Panas E., Element ufologiczny w Kościele scjentologicznym. Historia władcy Xenu, w: red. Kulty UFO, P. Czarnecki, A. Zaczkowska, Kraków 2014.

Park T., From the Church of Scientology to the Freezone, w: 'Cult Wars' in Historical Perspective: New and Minority Religions, red. E.V. Gallagher, London-New York 2017.

Pignotti M., My Nine Lives in Scientology, b.m.w. 1989.

Pouw K., Church of Scientology International and Religious Technology Center Win in Court Against Former Member, Release of the Church of Scientology International, 2.04.2010.

Rathbun M., The Scientology Reformation: What Every Scientologist Should Know [PDF], Scotts Valley 2012.

Raube S., Religia na granicy mitu, „IDEA - Studia nad strukturą i rozwojem pojęć filozoficznych” 2016, XXVIII, nr 2.

Reitman J., Inside Scientology: The Story of America's Most Secretive Religion, BostonNew York 2011.

Ritchie J., Tajemniczy świat sekt i kultów, tłum. I. Bajer, Warszawa 1994.

Ron Hubbard L. (?), Brain-washing: A Synthesis of the Russian Text Book on Psychopolitics [reprint 1959], Ch. Stickley (red.), Washington 1982.

Ron Hubbard L. Library, The L. Ron Hubbard Series - Master Mariner: At the Helm across Seven Seas, Glostrup 2012.

Ron Hubbard L., 2 D. Effective, „Flag Order” 13 January 1969, nr 1729.

Ron Hubbard L., Conditions of Space/Time/Energy. A Lecture given by L. Ron Hubbard on the 5. December 1952, w: Philadelphia Doctorate Course PDC, red. Ron's Org Grenchen, Grenchen 2010.

Ron Hubbard L., Cross, w: Modern Management Technology Defined. Shortened version, contains only the definitions, red. Church of Scientology of California, Los Angeles 1976.

Ron Hubbard L., Delivery, „The Auditor” 1970, nr 59.

Ron Hubbard L., Dianetyka: Współczesna nauka o zdrowiu umysłowym, Glostrup 2009.

Ron Hubbard L., Dynamiki istnienia, Copenhagen 2006.

Ron Hubbard L., Missionaire First Class, w: Modern Management Technology Defined. Shortened version, contains only the definitions, red. Church of Scientology of California.

Ron Hubbard L., Scjentologia. Nowe spojrzenie na życie, Glostrup 2009.

Ron Hubbard L., Scjentologia. Podstawy myśli - Podstawowa ksiq̨żka o teorii i praktyce Scjentologii dla poczq̨tkujq̨cych, Glostrup 2009, ss. 31. 
Ron Hubbard L., Sea Org Symbol, w: Modern Management Technology Defined. Shortened version, contains only the definitions, red. Church of Scientology of California, Los Angeles 1976.

Ron Hubbard L., The Creation of Human Ability - A Handbook for Scientologists, Copenhagen 2007.

Ron Hubbard Library L., The L. Ron Hubbard Series - Master Mariner: At the Helm across Seven Seas, Glostrup 2012.

Rothstein M., Space, Place and Religious Hardware: L. Ron Hubbard's Charismatic Authority in the Church of Scientology, w: Handbook of Scientology, red. J.R. Lewis, Leiden-Boston 2017.

Rowiński G., M. Purzycka, Inne niebo, czy w sieci szalonego proroka: nowe ruchy i sekty religijne w Polsce, Warszawa 1998.

Rybarczyk M., Scjentologia - kościół strachu, „Newsweek Polska” nr 26 z 24-30 czerwca $2013 \mathrm{r}$.

Sea Organization Success Denny Chang [ulotka propagandowa Sea Org], 2011.

Séguy J., A Sociology of Imagined Societes: Monasticism and Utopia, w: Annual Review of the Sociology of Religion: Volume 5: Sociology and Monasticism. Between Innovation and Tradition, red. I. Jonveaux, E. Pace, S. Palmisano, Leiden-Boston 2014.

Townsend E., The Sad Tale of Scientology: A short history 1950-1985, Stockport 1985.

Urban H.B., The Church of Scientology: A History of a New Religion, Princeton 2011.

Urban H.B., The Occult Roots of Scientology? L. Ron Hubbard, Aleister Crowley, and the Origins of a Controversial New Religion, „Nova Religio: The Journal of Alternative and Emergent Religion” 2012, vol. 15, nr 3.

Vosper C., The Mind Benders. Scientology [PDF], London 1971.

Wakefield M., Understanding Scientology: The Demon Cult, Raleigh 2010.

Wallis R., The Road to Total Freedom: A Sociological Analysis of Scientology, New York 1977.

Westbrook D., Among the Scientologists: History, Theology, and Praxis, New York 2018.

Woodstock R., Scientology and UFOs, w: Inside Scientology. The story of America's Most Secretive Religions, „Vision Report Watch” 2012, nr 21.

Wright L., Droga do wyzwolenia. Scjentologia, Hollywood i pułapki wiary, tłum. A. Wilga, Wołowiec 2015.

Ziegler G., Tarot: Mirror of the Soul. Handbook for the Aleister Crowley Tarot, York 1991.

Zimniak-Hałajko M., Raj oswojony. Antropologia nowych ruchów religijnych, Gdańsk 2003.

Zwoliński A., Scjentologia, Kraków 2007.

Zwoliński A., Sekty w ekonomii, „Cywilizacja” 2002, nr 3.

Дворкин А.Л., Сектоведение. Тоталитарные секты. Опыт систематического исследования, Нижний Новгород 2014.

Кукушкина Г.А., Церковь Саентологии: основы вероучения, культовая и внекультовая практика (социально-философский анализ), Москва 2003.

Одинцов М.И., Лафайет Рональд Хаббард: биография человека, w: Свобода совести в России: исторический и современный аспекты. Выпуск 7. Сборник статей, red. М.И. Одинцов, Н.И. Щемелёва, Л.А. Ли, Санкт-Петербург 2009.

Трофимов Я.Ф, Церковь Саентологии. Опыт религиоведческого анализа, Алматы 2006. 
